\title{
Induction of apoptosis in the SW620 colon carcinoma cell line by triterpene-enriched extracts from Ganoderma lucidum through activation of caspase- 3
}

\author{
ZHE JI $^{1,2}$, QINGJIU TANG ${ }^{1}$, RUIXIA HAO ${ }^{1}$, JINSONG ZHANG ${ }^{1}$ and YINGJIE PAN ${ }^{3}$ \\ ${ }^{1}$ National Engineering Research Center of Edible Fungi, Key Laboratory of Applied Mycological Resources and Utilization, \\ Ministry of Agriculture, Shanghai Key Laboratory of Agricultural Genetics and Breeding, Institute of Edible Fungi, \\ Shanghai Academy of Agricultural Sciences, Shanghai 201106; ${ }^{2}$ Key Laboratory of Nutrition and Metabolism, \\ Institute for Nutritional Sciences, Shanghai Institutes for Biological Sciences, Chinese Academy of \\ Sciences, Shanghai 200031; ${ }^{3}$ Shanghai Fisheries University, Shanghai 200090, P.R. China
}

Received December 9, 2010; Accepted March 14, 2011

DOI: $10.3892 / 01.2011 .275$

\begin{abstract}
The medicinal mushroom Ganoderma lucidum (G. lucidum) has been used for the treatment of various diseases, and is known for the immune-enhancing activity of its polysaccharide. However, little is known about another of its major constituents, triterpene. This study investigated the anticancer mechanism of a triterpene-enriched extract from G. lucidum. The triterpene-enriched extract, GLAI, was prepared from fruiting bodies of $G$. lucidum by sequential hot water extraction, removal of ethanol-insoluble polysaccharides and gel-filtration chromatography. The mechanisms of GLAI-induced apoptosis on SW620 human colorectal adenocarcinoma cells were investigated. Tumor cell lines in vitro were treated with different concentrations of GLAI. Cell proliferation was measured by the Alamar blue assay, morphology of cell apoptosis was observed, cell apoptosis was detected by flow cytometry (FCM) and caspase-3 activity was detected by Caspase- 3 cellular activity assay. The results showed that GLAI inhibited the growth of different tumor cells and caused significant apoptosis in a dose-dependent manner. Marked morphological changes of cell apoptosis were observed after the cells had been exposed to GLAI for $24 \mathrm{~h}$. The Caspase- 3 assay results showed that the activity of the caspase-3 enzyme increased in both a time- and dose-dependent manner, whereas GLAI resulted in the down-regulation of Bcl-2 gene expression at the mRNA level and XIAP protein production at the protein level. Conversely, GLAI up-regulates the expression of the apoptosis enhancer Bax gene and p53 protein. These findings suggest that the triterpenes contained in G. lucidum are potential anticancer agents.
\end{abstract}

Correspondence to: Dr Qingjiu Tang, Institute of Edible Fungi, Shanghai Academy of Agricultural Sciences, Shanghai 201106, P.R. China

E-mail: jizhe2008@gmail.com

Key words: apoptosis, Ganoderma lucidum, triterpene

\section{Introduction}

Ganoderma lucidum (G. lucidum), known as 'Lingzhi' in China, is a lamella-less basidiomycetous fungus that belongs to the Polyporaceae family. The medicinal properties of this mushroom are well known in China and other parts of Asia. Known as 'miraculous Zhi' or 'auspicious herb', Lingzhi is considered to 'symbolize happy augury, and to bespeak good fortune, good health and longevity, even immortality' (1). The fungus has been used as a traditional Chinese medicine to treat a variety of diseases for more than 4,000 years, and regular consumption of the mushroom extracts is believed to preserve human vitality and promote longevity $(2,3)$.

A number of bioactive components have been identified from its fruit bodies, mycelia, spores and culture media. Polysaccharides and triterpenes are two major categories of the bioactive ingredients. It was previously identified that polysaccharides from G. lucidum exert their in vitro and in vivo anticancer effect via an immune-modulatory mechanism (4-6). Studies showed that triterpenes possess the bioactivities of antioxidation (7), hepatoprotection (8), cholesterol stasis (9), anti-hypertension $(10,11)$ and inhibiting platelet aggregation (12) due to the inhibition of enzymes such as h-galactosidase, cholesterol synthase and angiotension-converting enzyme. Triterpenes isolated from G. lucidum were reported to exhibit cytotoxic activity against tumor cells (13-16). A triterpene from Ganoderma tsugae was found to induce cell apoptosis and cell cycle arrest in human hepatoma Hep3B cells, but its molecular mechanism was not investigated (13).

Apoptosis is a form of cell death defined by a characteristic set of morphological and biochemical changes. Previous studies identified a significant role for caspases, a family of cysteine-dependent aspartate-directed proteases, in apoptotic death, especially in the context of cancer cells (17). Individual members of the caspase family mediate apoptosis in different cell types, and different caspases have been found to mediate apoptosis even within a given cell type depending on the apoptotic stimulus received by the cells (18). Caspase-3 and -9 are reported to play key roles in caspase-mediated apoptosis, 
and variations in their activity were correlated with apoptosis in a variety of cancer cells $(19,20)$.

In this study, we report that a triterpene-enriched fraction from mycelia of $G$. lucidum inhibits the growth of tumor cells and induces apoptosis in SW620 colorectal adenocarcinoma cells. Consequently, the anticancer mechanism of GLAI-induced apoptosis on SW620 human colorectal adenocarcinoma cells was examined. Findings present evidence of the signaling molecule involved in the anticancer activity of triterpene from G. lucidum.

\section{Materials and methods}

Preparation of ganoderma extracts. G. lucidum fruiting bodies were extracted with $95 \%(\mathrm{v} / \mathrm{v})$ aqueous ethanol at room temperature. Combined ethanolic extracts were evaporated to dryness, redissolved in water and extracted with chloroform. After addition of a saturated $\mathrm{NaHCO}_{3}$ solution, the chloroform layer containing non-acidic triterpenoids was collected. The crude extracts were purified using silica gel (200-300 mesh) column chromatography. The column was eluted with petrol ether/acetone ( $\mathrm{v} / \mathrm{v}=1: 0,50: 1,30: 1,10: 1,3: 1$ sequentially) and eight fractions were collected. The second fraction was separated further by MCI chromatography and the elution gradient was $40-100 \%$ methanol in water. The fifth fraction, obtained with $80 \%$ methanol elution, was termed GLAI. Triterpenes were visualized as fluorescent spots under long wavelength UV light.

Cell cultures. Human tumor cell lines, SW620 cells (colon), MCF-7 (breast), K562 (bone marrow), and mouse lymphocytic leukemia cell line L1210 were obtained from the American Type Culture Collection (ATCC) and maintained at $37^{\circ} \mathrm{C}$ in RPMI-1640 containing $10 \%$ fetal calf serum (FCS) (Kraeber, Wedel, Germany), $100 \mathrm{U} / \mathrm{ml}$ penicillin and $100 \mu \mathrm{g} / \mathrm{ml}$ streptomycin.

Cell proliferation assay. Cells were adjusted to a concentration of $1 \times 10^{4}$ cells $/ \mathrm{ml}$. Cell suspension $(180 \mu \mathrm{l})$ and different test agents $(20 \mu \mathrm{l})$ were added to each well of a 96 -well microplate reader. After incubation at $37^{\circ} \mathrm{C}$ in a $5 \% \mathrm{CO}_{2}$ atmosphere for a defined time, $20 \mu \mathrm{l}$ Alamar Blue reagent (Biosource, Nivelles, Belgium) were added to each well and incubation continued for another $6 \mathrm{~h}$. The extinction was measured using a micro ELISA autoreader at 570 and $600 \mathrm{~nm}$. The proliferation rate was calculated according to the Biosource protocol.

Microscopic observation and nuclear staining with Hoechst 33258. SW620 cells $\left(1 \times 10^{4}\right.$ cells $\left./ \mathrm{ml}\right)$ were treated for $24 \mathrm{~h}$ with a control and $10 \mu \mathrm{M}$ GLAI. Morphological observations of cultured cells were made by inverted, phase-contrast microscopy. Samples treated with DMSO only served as controls. For nuclear staining, SW620 cells $\left(1 \times 10^{5}\right.$ cells $\left./ \mathrm{ml}\right)$ were treated for $24 \mathrm{~h}$ with DMSO and 10, 50 and $100 \mu \mathrm{M}$ GLAI. After treatment, cells were harvested and washed with ice-cold phosphate-buffered saline (PBS). The cells were then incubated in nuclear fluorochrome Hoechst 33258 at a final concentration of $10 \mu \mathrm{g} / \mathrm{ml}$ at room temperature for $10 \mathrm{~min}$ in the dark. Nuclear morphology was then examined with an Olympus fluorescent microscope.
Flow cytometric analysis of apoptosis. To confirm the nature of the effects of GLAI on SW620 cells, dual-staining [propidium iodide (PI) and annexin V (AV)] flow cytometry was used to measure the externalization of phosphatidylserine (PS). Aliquots $\left(5 \times 10^{6}\right)$ of SW620 cells cultured as described above were treated with 20,50 or $100 \mu \mathrm{mol} / 1$ GLAI for $24 \mathrm{~h}$. Controls were treated with DMSO only. After washing and trypsinization, cell samples were collected by centrifugation (400 g, $3 \mathrm{~min}, 4^{\circ} \mathrm{C}$ ) and double-stained using the apoptosis detection kit (BD Biosciences, San Jose, CA, USA) according to the manufacturer's instructions. Cells were incubated for $30 \mathrm{~min}$ at $25^{\circ} \mathrm{C}$ in $100 \mu \mathrm{l} 1 \mathrm{X}$ buffer solution, $5 \mu 1 \mathrm{AV}$-FITC and $5 \mu \mathrm{l} \mathrm{PI}$, and then a further $400 \mu \mathrm{l}$ of $1 \mathrm{X}$ solution was added. The green fluorescence of AV-FITC-bound PS and the red fluorescence of DNA-bound PI in individual cells were measured at 525 and $575 \mathrm{~nm}$, respectively, using a BD FACSCalibur. Cell populations were classified as: $\mathrm{AV}^{-} / \mathrm{PI}^{-}$, viable cells; $\mathrm{AV}^{+} / \mathrm{PI}^{-}$, early apoptotic cells; $\mathrm{AV}^{+} / \mathrm{PI}^{+}$, apoptotic cells; and $\mathrm{AV}^{-} / \mathrm{PI}^{+}$, residual damaged cells.

Caspase-3 activity assay. Caspase-3 activity in the lysates of SW620 cells was measured using the Caspase-3 cellular activity assay (Calbiochem, Darmstadt, Germany). SW620 cells were cultured as described above and suspensions $\left(2 \times 10^{7}\right.$ cells) were treated with different concentrations of $\operatorname{GLAI}(0,10,25$ and $50 \mu \mathrm{mol} / \mathrm{l})$ for $24 \mathrm{~h}$. Controls were treated with DMSO only. After washing and trypsinization, cell suspensions were centrifuged $\left(400 \mathrm{~g}, 3 \mathrm{~min}, 4^{\circ} \mathrm{C}\right)$ and cell pellets were re-suspended in $1 \mathrm{ml}$ ice-cold cell lysis buffer for $5 \mathrm{~min}$. Following centrifugation (400 g, $3 \mathrm{~min}$, $4^{\circ} \mathrm{C}$ ), cytosol supernatants were collected and enzyme activity was measured according to the manufacturer's instructions. Reaction mixtures (total volume $100 \mu \mathrm{l}$ ) were incubated at $37^{\circ} \mathrm{C}$ for $10 \mathrm{~min}$ and the optical density value was measured for $15 \mathrm{~h}$ at $405 \mathrm{~nm}$ using an ELISA reader (Bio-Tek, Atlanta, GA, USA).

Reverse transcription-polymerase chain reaction (RT-PCR). For RNA extraction, two experiments were performed. Firstly, SW620 cells $\left(3.6 \times 10^{6}\right.$ cells $\left./ \mathrm{ml}\right)$ were incubated in RPMI-1640 containing $10 \% \mathrm{FCS}$ and different concentrations of GLAI $(10,50$ and $100 \mu \mathrm{g} / \mathrm{ml})$. The entry with $0 \mu \mathrm{g} / \mathrm{ml}$ GLAI , treated with DMSO, was used as a negative control. The cells were cultured for $24 \mathrm{~h}$ at $37^{\circ} \mathrm{C}, 5 \% \mathrm{CO}_{2}$, in a humidified incubator. Secondly, SW620 cells $\left(2 \times 10^{6} / \mathrm{ml}\right)$ were incubated in RPMI1640 containing $10 \%$ FCS and GLAI $(50 \mu \mathrm{g} / \mathrm{ml})$. The cells were cultured for $0,6,12,18$ and $24 \mathrm{~h}$ at $37^{\circ} \mathrm{C}, 5 \% \mathrm{CO}_{2}$.

The cells were lysed in TRIzol reagent (Invitrogen Life Technologies). Total RNA was extracted according to the manufacturer's instructions. The RNA pellet was dissolved in diethyl pyrocarbonate (DEPC)-treated water prior to use for reverse transcription, electrophoresed on a $1.5 \%$ agarose gel and visualized by ethidium bromide (EB) staining under an ultraviolet light, and two bands (28S and 18S) are evident.

RNA was primed with oligo(dT)15 and converted into complementary DNA (cDNA) by Moloney murine leukemia virus (MMLV) reverse transcriptase. The reaction mixture for reverse transcription contained 5.0X buffer, $2.5 \mathrm{mM}$ of each deoxynucleotriphosphate (dNTP, i.e., dATP, dCTP, dGTP and dTTP), $40 \mathrm{U} / \mu 1 \mathrm{RNase}$ inhibitor, $200 \mathrm{U} / \mu 1$ reverse 
Table I. List of polymerase chain reaction primers.

\begin{tabular}{ll}
\hline Genes & \multicolumn{1}{c}{ Primer sequences } \\
\hline GAPDH & \\
Sense & 5' TGA AGG TCG GAG TCA ACG GAT TTG GT 3' \\
Antisense & 5' CAT GTG GGC CAT GAG GTC CAC CAC 3' \\
Bcl-2 & \\
Sense & 5' TGC ACC TGA CGC CCT TCA C 3' \\
Antisense & 5' AGA CAG CCA GGA GAA ATC AAA CAG 3' \\
Bax & \\
Sense & 5' ACC AAG AAG CTG AGC GAG TGT C 3' \\
Antisense & 5' ACA AAG ATG GTC ACG GTC TGC C 3' \\
\hline
\end{tabular}

Glyceraldehyde 3-phosphate dehydrogenase.

transcriptase, $10 \mu \mathrm{M}$ oligo(dT) 15 and $2 \mu \mathrm{g}$ total RNA (equal amounts of starting RNA were used for each condition in the different experiments). The final volume of the reaction was $30 \mu \mathrm{l}$. The program parameters were $70^{\circ} \mathrm{C}$ for $5 \mathrm{~min}$ to heat, $37^{\circ} \mathrm{C}$ for $1.5 \mathrm{~h}$ for reverse transcription reaction and $95^{\circ} \mathrm{C}$ for $5 \mathrm{~min}$ to inactivate the reverse transcriptase. cDNA generated by reverse transcription was either used immediately for PCR experiments for the cytokines of interest or stored at $-20^{\circ} \mathrm{C}$.

Oligonucleotide primers for GAPDH, Bcl-2 and Bax were purchased from Invitrogen Life Technologies (Carlsbad, CA, USA). Table I shows the sequence primers and the sizes of the fragments generated by the PCR reactions.

The components added to the sample to make up $20 \mu \mathrm{l}$ reaction mixture were: $1 \mu \mathrm{l} \mathrm{cDNA}, 2 \mu \mathrm{l} 10 \mathrm{X}$ Taq DNA polymerase buffer, $2 \mu \mathrm{l} 25 \mathrm{mM} \mathrm{Mg}^{2+}$ (Promega, Madison, WI, USA), $0.5 \mu \mathrm{l}$ $10 \mathrm{mM}$ mixture of all four deoxynucleotide triphosphates (Promega), $0.5 \mu \mathrm{l}$ each of $5^{\prime}$ and $3^{\prime} \operatorname{primer}(10 \mu \mathrm{M})$ and 1 unit Taq DNA polymerase (Promega). PCR was performed for 35 cycles. Temperature cycling was initiated with each cycle as follows: for GAPDH, $95^{\circ} \mathrm{C}$ for $45 \mathrm{sec}$ (denaturation), $58^{\circ} \mathrm{C}$ for $45 \mathrm{sec}$ (annealing), $72^{\circ} \mathrm{C}$ for $30 \mathrm{sec}$ (extension); for Bcl-2, $95^{\circ} \mathrm{C}$ for $45 \mathrm{sec}, 56^{\circ} \mathrm{C}$ for $45 \mathrm{sec}, 72^{\circ} \mathrm{C}$ for $30 \mathrm{sec}$; for Bax, $95^{\circ} \mathrm{C}$ for $45 \mathrm{sec}, 58^{\circ} \mathrm{C}$ for $45 \mathrm{sec}$ and $72^{\circ} \mathrm{C}$ for $30 \mathrm{sec}$. The amplified products were detected in $1.5 \%$ agarose gels stained with $\mathrm{EB}$ and visualized under UV light.

Western-blot analysis. For the analysis of p53 and XIAP, SW620 cells $\left(3.6 \times 10^{6} / \mathrm{ml}\right)$ were incubated in RPMI-1640 containing 10\% FCS and different concentrations of GLAI $(10,20,50$ and $100 \mu \mathrm{g} / \mathrm{ml})$. The entry with $0 \mu \mathrm{g} / \mathrm{ml}$ GLAI, treated with DMSO, was used as a negative control. The cells were cultured for $24 \mathrm{~h}$ at $37^{\circ} \mathrm{C}, 5 \% \mathrm{CO}_{2}$, in a humidified incubator. Cells were washed twice with PBS and lysed in lysis buffer containing $50 \mathrm{mM}$ Tris- $\mathrm{HCl}(\mathrm{pH} 8.0), 150 \mathrm{mM} \mathrm{NaCl}$, $1 \%$ Triton X-100 and $100 \mu \mathrm{g} / \mathrm{ml}$ PMSF at $4^{\circ} \mathrm{C}$ overnight. The suspensions were then centrifuged at $12,000 \mathrm{rpm}$ for $5 \mathrm{~min}$; All lysates were subjected to BCA protein assay reagent (Pierce, Rockford, IL, USA) for the quantification of protein concentration, and then Western blot analysis was performed. Total proteins $(20-50 \mu \mathrm{g})$ were separated by sodium dodecyl sulfate-polyacrylamide gelelectrophoresis using a $10 \%$ polyacrylamide gel. The proteins in the gel were transferred to

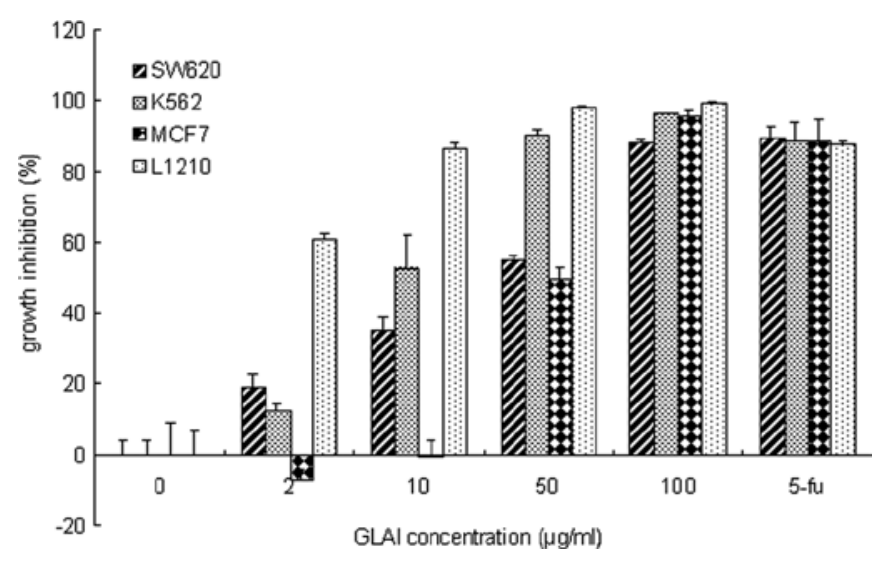

Figure 1. Effect of GLAI on the growth of different tissue cell lines. Cells were treated for $72 \mathrm{~h}$ with different concentrations of GLAI (2, 10, 50 and $100 \mu \mathrm{g} / \mathrm{ml}$ ) dissolved in DMSO. Negative controls were treated with DMSO only and positive controls were treated with 5-fluorouracil $(1 \mu \mathrm{g} / \mathrm{ml})$. Values are the mean \pm SD. Experiments were performed in triplicate, $\mathrm{p}<0.001$.

a PVDF membrane. The membrane was blocked with $0.1 \%$ BSA in TBST for $1 \mathrm{~h}$. Membranes were incubated with primary antibody $(1: 2,000)$ at $4^{\circ} \mathrm{C}$ overnight and then with secondary antibody $(1: 2,000)$ for $1 \mathrm{~h}$. The membranes were washed three times in TBST for 10 min between each step. The signal was detected using the Amersham ECL system (Amersham-Pharmacia Biotech, Arlington Heights, IL, USA).

Statistical analysis. The data are shown as the means \pm SD. The Student's t-test was used to determine the significance of differences between population means with results considered as: significant, $\mathrm{p}<0.05$; very significant, $\mathrm{p}<0.01$; extremely significant, $\mathrm{p}<0.001$.

\section{Results}

Cell proliferation assay. To determine the effect of GLAI on different tumor cells, the proliferation assay was performed using the Alamar blue. As shown in Fig. 1, GLAI at a concentration of $2 \mu \mathrm{mol} / 1$ inhibited the growth of SW620, K562 and L1210 cells to $\sim 19,12$ and $60 \%$, respectively. Exposure of the SW620, K562 and L1210 cells to $10 \mu \mathrm{mol} / \mathrm{l}$ GLAI inhibited 

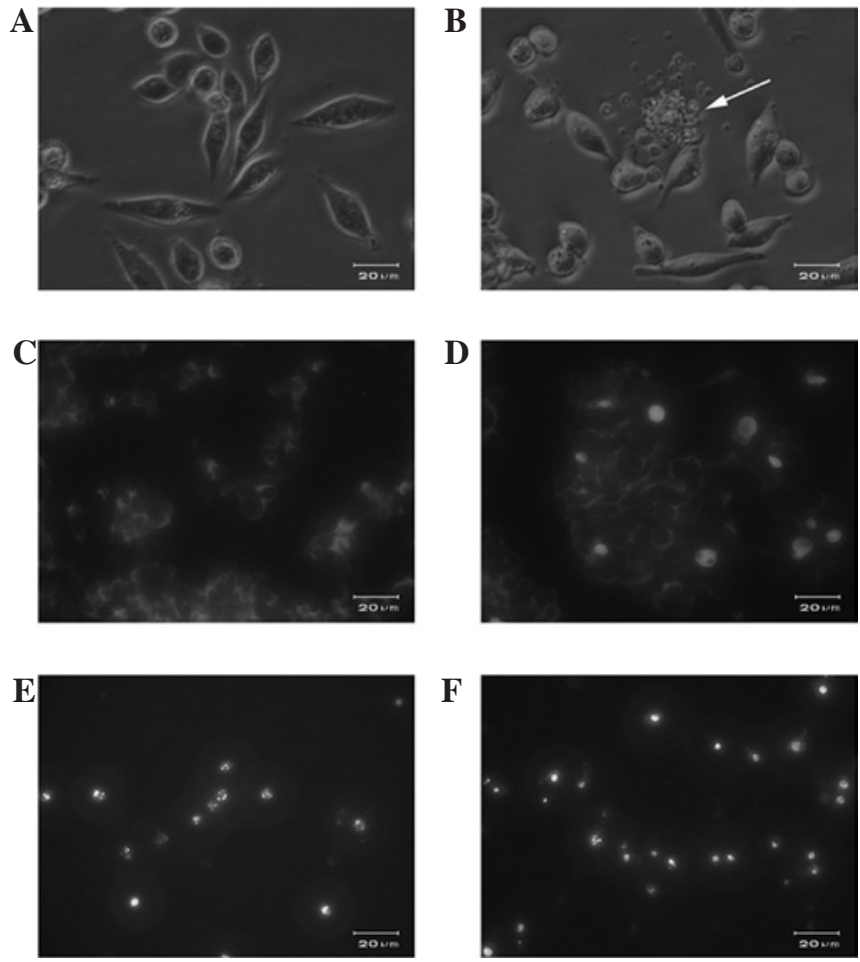

Figure 2. Photomicrographs of SW620 exposed to (A) DMSO and (B) $10 \mu \mathrm{g} /$ $\mathrm{ml}$ GLAI for $24 \mathrm{~h}$; the arrow indicates apoptotic bodies. Fluorescence microscopy of SW620 cells using DNA fluorochrome Hoechst 33258. SW620 cells were treated with different concentrations of GLAI for $24 \mathrm{~h}$. (C) DMSO, (D) $10 \mu \mathrm{g} / \mathrm{ml} \mathrm{GLAI,} \mathrm{(E)} 50 \mu \mathrm{g} / \mathrm{ml}$ GLAI and (F) $100 \mu \mathrm{g} / \mathrm{ml}$ GLAI.

cell growth by 35,52 and $86 \%$. respectively. However, no additional effect was observed with MCF7 cells at these concentrations (Fig. 1). However, increased growth inhibition of SW620, K562, MCF7 and L1210 cells (to 55, 90 and 98\%, respectively) was observed following exposure to $50 \mu \mathrm{mol} / 1$ GLAI. Treatment with $100 \mu \mathrm{mol} / 1$ GLAI resulted in almost total inhibition of cell growth and few viable cells (see below) in all cases. Positive controls treated with 5-fluorouracil were inhibited $88-90 \%$ under these conditions.
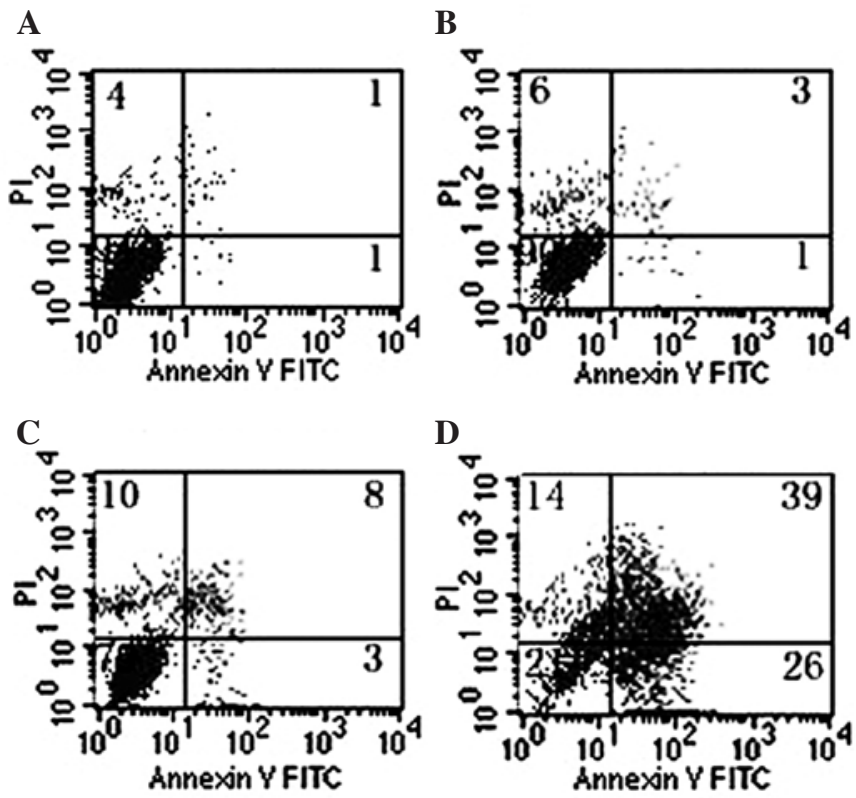

Figure 3. FACS analysis of annexin V (AV) and propidium iodide (PI) binding. SW620 cells were treated with DMSO or GLAI (20, 50 or $100 \mu \mathrm{g} /$ $\mathrm{ml}$ ) for $24 \mathrm{~h}$ as described in Materials and methods. PI and AV-FITC fluorescence was measured by flow cytometry and analyzed (dot-plots). Viable $(\mathrm{AV} / \mathrm{PI})$, early apoptotic $\left(\mathrm{AV}^{+} / \mathrm{PI}\right)$, apoptotic $\left(\mathrm{AV}^{+} / \mathrm{PI}^{+}\right)$and residual damaged $\left(\mathrm{AV}^{-} / \mathrm{PI}^{+}\right)$cells are shown in the respective quadrants.

Microscopic observation. Normally adhesive SW620 cells were readily suspended following treatment with $10 \mu \mathrm{mol} / \mathrm{l}$ GLAI for $24 \mathrm{~h}$, and few viable cells were observed following exposure to $50 \mu \mathrm{mol} / \mathrm{l} \mathrm{GLAI}$ (data not shown). Light microscopy showed that cells exposed to DMSO (Fig. 2A) or $10 \mu \mathrm{mol} / 1$ GLAI exhibited distinct morphological features, such as apoptotic bodies, associated with programmed cell death (Fig. 2B).

To further determine the nuclear morphology of SW620 cells treated with GLAI, Hoechst 33258 staining was performed. Following treatment of SW620 cells with different

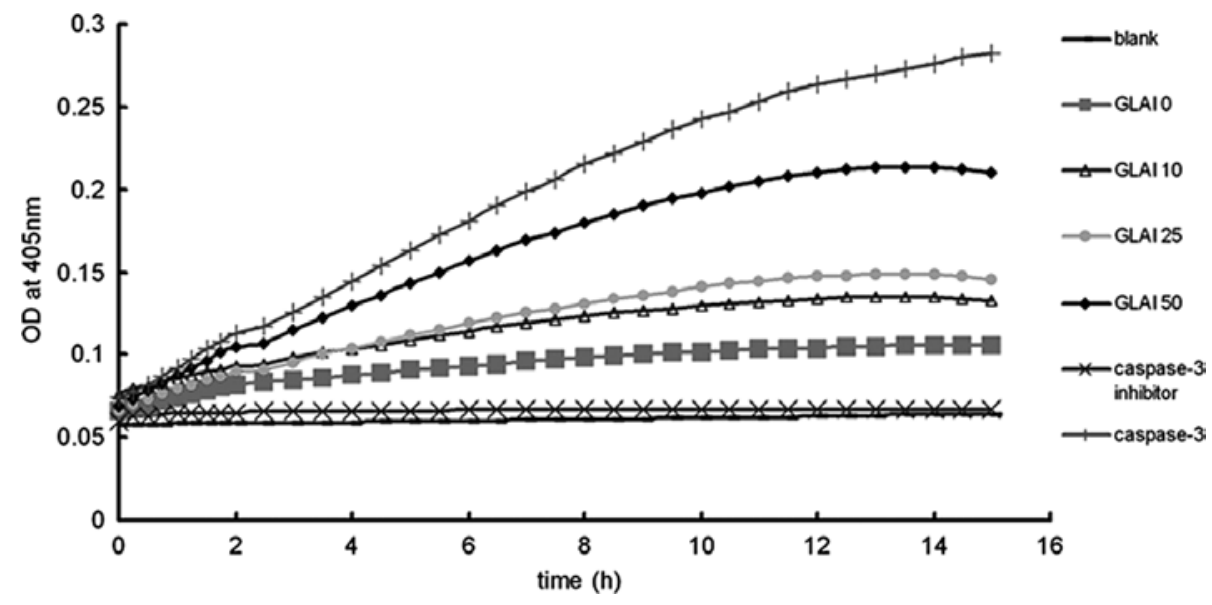

Figure 4. Analysis of caspase-3 activity. SW620 cells were treated with different concentrations of GLAI (10, 25 and $50 \mu \mathrm{g} / \mathrm{ml}$ ). Caspase-3 activity was monitored and three negative controls were observed: the blank well had only assay buffer added, the GLAI 0 well had DMSO-treated cell extract added and the inhibitor well had inhibitor-treated cell extract added. The positive control was purified caspase-3. 


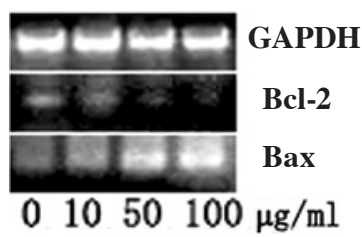

B

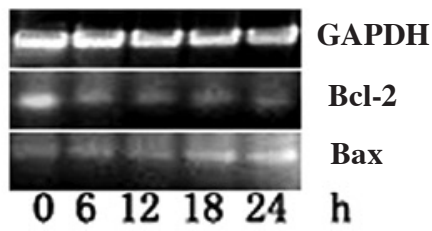

C

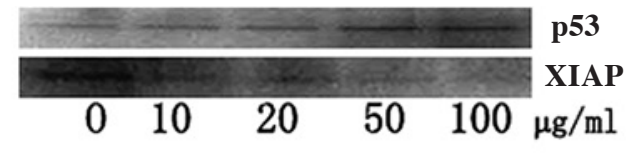

Figure 5. Molecular responses in SW620 cells treated with GLAI. Expression of apoptosis mRNA proteins in SW620 cells exposed to GLAI. SW620 cells were treated with different concentrations of GLAI for $24 \mathrm{~h}$ (A) or $50 \mu \mathrm{g} / \mathrm{ml}$ GLAI for different times (B), internal standard gene was GAPDH. (C) Expression of apoptosis proteins in SW620 cells exposed to different concentrations of GLAI. SW620 cells were treated with different concentrations of GLAI (10, 20, 50 and $100 \mu \mathrm{g} / \mathrm{ml}$ ). DMSO served as the negative control.

concentrations of GLAI for $24 \mathrm{~h}$, the chromatin stained with Hoechst 33258 had a characteristic condensed and fragmented appearance (Fig. 2C-F).

Flow cytometry. The staining patterns of SW620 cells exposed to GLAI for $24 \mathrm{~h}$ and treated with AV-FITC and PI are shown in Fig. 3. More than $94 \%$ of cells remained viable following treatment for $24 \mathrm{~h}$ with DMSO alone (negative control) and almost no apoptotic events were detected (Fig. 3, lower left quadrant). However, the proportion of cells with externalized PS increased in cells following treatment for $24 \mathrm{~h}$ with different concentrations of GLAI (Fig. 3).

Activation of caspase-3 by treatment with GLAI. Caspases are significant mediators of apoptosis in mammalian cells (21), therefore, we measured caspase-3 activities. When SW620 cells were treated with different concentrations of GLAI, intracellular caspase-3 activity was analyzed (Fig. 4). Caspase-3 activity was found to be up-regulated in SW620 cells in a dose-dependent manner.

Molecular events responding to GLAI-treatment. In order to understand the induction mechanism of apoptosis by GLAI, we examined the expression levels of Bcl-2 and Bax using RT-PCR, as well as p53 and XIAP using Western blotting. The treatment of the SW620 cells with GLAI resulted in a marked decrease of Bcl-2 at mRNA levels in a dose-dependent manner (Fig. 5A). By contrast, the Bax mRNA expression level was increased in a dose-dependent manner (Fig. 5B). The results of Western blotting showed that the p53 protein expression level was up-regulated after SW620 cells were treated with different concentrations of GLAI. By contrast, the XIAP protein expression level was down-regulated (Fig. 5C).

\section{Discussion}

Colon cancer is a common cause of death among cancer patients worldwide. Dysregulation of the normal colonic epithelium is the causative factor of neoplastic transformation caused by alterations in various parameters, including epithelial cell proliferation and apoptosis. The latter two processes are highly regulated in the constantly regenerating non-transformed colonic epithelium and involve adhesion molecules, cytoskeletal proteins, cell cycle regulators and apoptosis (22).

Annexin $\mathrm{V}$ is a protein that exhibits specific affinity for PS. In non-apoptotic cells, most PS molecules are localized on the inner leaflet of the plasma membrane, but shortly after the onset of apoptosis, PS redistributes to the outer layer of the membrane (23). Cells in the early stages of apoptosis usually bind AV-FITC in the absence of PI uptake (lower right quadrant), while those in the late stages of apoptosis bind AV-FITC and in the presence of PI uptake (upper quadrant).

Caspases are a family of intracellular cysteine proteases with specificity for aspartic acid residues and play important roles in drug-inducing apoptosis in a large variety of cancer cells $(24,25)$. Two members of this group of enzymes, known as 'initiator' and 'effector' caspases, also play a significant role in the apoptotic process $(25,26)$. Caspase- 3 is the common effector for most apoptotic pathways (19) and appears to play a special role as a key 'executioner' in that its active form is responsible for the cleavage and breakdown of several cellular components related to DNA repair and regulation. Once activated, caspase-3 is able to cleave a number of important cellular substrates and causes membrane blebbing, disassembly of the cell structure and DNA fragmentation, which eventually lead to cell death. Some initiator caspases, such as caspase-9, activate pro-caspase-3, which then cleaves the cellular substrates needed for the orchestration of apoptosis and forms a 'wheel of death' (19,25-27). Findings of studies have shown that apoptosis, especially caspase-mediated cell death, plays an important role in the etiology, pathogenesis and therapy of a variety of human malignancies, such as human hepatocellular carcinoma. Additionally, the cytotoxic effects of most anti-hepatocellular carcinoma drugs are based on apoptosis induction (28). These studies indicate that induction of apoptosis may be an index for new anti-tumor drug selection and an important method of assessing the clinical efficacy of many anti-carcinoma drugs (17).

Moreover, we found that the increase in caspase-3 activation is synchronized with the increase in Bax expression and the decrease in Bcl-2, which is in agreement with other studies (29-31). The Bcl-2 family of proteins plays a crucial role in the regulation of apoptosis in many cellular systems, by either inhibiting (Bcl-2, Bcl-XL, Bcl-W, Bfl-1 and Mcl-1) or promoting apoptosis (Bax, Bak, Bad, Bcl-Xs, Bid and Hrk) $(32,33)$. Heterodimerization between pro- and anti-apoptotic members of this family and relative levels of the two types of proteins may determine the susceptibility to a given apoptotic stimulus and the cell fate $(34,35)$. Moreover, these genes are known to be crucial regulators of apoptosis in colon cancer cell lines $(36,37)$.

In conclusion, our study has shown that GLAI inhibits the growth of SW620 cells by inducing apoptosis via the activation of caspase-3. These findings provide a basis for further investigation of triterpenes from G. lucidum in the treatment and prevention of colorectal adenocarcinoma. 


\section{Acknowledgements}

The authors thank Mr. Hengbing Shi for the technical assistance and Dr John Buswell for the linguistic revision of the manuscript. This study was supported by the National Science Foundation of China (30801031 to Z. Ji) and China Postdoctoral Science Foundation (to Z. Ji).

\section{References}

1. Wasson RG: Soma-Divine Mushroom of Immortality. Harcourt, Brace \& World, New York, p381, 1968.

2. Chang ST and Buswell JA: Ganoderma lucidum (Curt.:Fr) P. Karst. (Aphyllophoromycetideae) - a mushrooming medicinal mushroom. International Journal of Medicinal Mushrooms 1: 139-146, 1999.

3. Wachtel-Galor S, Benzie IFF; Tomlinson B and Buswell JA: Lingzhi (Ganoderma lucidum): molecular aspects of health effects. In: Herbal Medicines. Packer L, Halliwell B and Ong CN, (eds). Marcel Dekker Inc., New York, pp179-228, 2004.

4. Furusawa E, Chou SC, Furusawa S, Hirazumi A and Dang Y: Antitumor activity of Ganoderma lucidum, an edible mushroom, on intraperitoneal implanted Lewis lung carcinoma in syngeneic mice. Phytotherapy Research 6: 300-304, 1992.

5. Lieu CW, Lee SS and Wang SY: The effect of Ganoderma lucidum on induction of differentiation in leukemic U937 cells. Anticancer Res 12: 1211-1215, 1992.

6. Wang SY, Hsu ML, Hsu HC, et al: The anti-tumor effect of Ganoderma lucidum is mediated by cytokines released from activated macrophages and $\mathrm{T}$ lymphocytes. Int $\mathrm{J}$ Cancer 70 : 699-705, 1997.

7. Zhu M, Chang Q, Wong LK, Chong FS and Li RC: Triterpene antioxidants from ganoderma lucidum. Phytother Res 13: 529-531, 1999.

8. Kim DH, Shim SB, Kim NJ and Jang IS: Beta-glucuronidaseinhibitory activity and hepatoprotective effect of Ganoderma lucidum. Biol Pharm Bull 22: 162-164, 1999.

9. Komoda Y, Shimizu M, Sonoda Y and Sato Y: Ganoderic acid and its derivatives as cholesterol synthesis inhibitors. Chem Pharma Bull 37: 531-533, 1989.

10. Kabir Y, Kimura S and Tamura T: Dietary effect of Ganoderma lucidum mushroom on blood pressure and lipid levels in spontaneously hypertensive rats (SHR). J Nutr Sci Vitaminol 34: 433-438, 1988

11. Lee SY and Rhee HM: Cardiovascular effects of mycelium extract of Ganoderma lucidum: inhibition of sympathetic outflow as a mechanism of its hypotensive action. Chem Pharma Bull 38: 1359-1364, 1990.

12. Su CY, Shiao MS and Wang CT: Differential effects of ganodermic acid $\mathrm{S}$ on the thromboxane A2-signaling pathways in human platelets. Biochem Pharmacol 58: 587-595, 1999.

13. Gan KH, Fann YF, Hsu SH, Kuo KW and Lin $\mathrm{CN}$ : Mediation of the cytotoxicity of lanostanoids and steroids of Ganoderma tsugae through apoptosis and cell cycle. J Nat Prod 61: 485-487, 1998.

14. Min BS, Gao JJ, Nakamura N and Hattori M: Triterpenes from the spores of Ganoderma lucidum and their cytotoxicity against meth-A and LLC tumor cells. Chem Pharma Bull 48: 1026-1033, 2000.

15. Noda Y, Kaiya T, Kohda K and Kawazoe Y: Enhanced cytotoxicity of some triterpenes toward leukemia L1210 cells cultured in low $\mathrm{pH}$ media: possibility of a new mode of cell killing. Chem Pharma Bull 45: 1665-1670, 1997.
16. Wu TS, Shi LS and Kuo SC: Cytotoxicity of Ganoderma lucidum triterpenes. J Nat Prod 64: 1121-1122, 2001.

17. Beauparlant $P$ and Shore GC: Therapeutic activation of caspases in cancer: a question of selectivity. Curr Opin Drug Discov Devel 6: 179-187, 2003.

18. Thorburn A: Death receptor-induced cell killing. Cell Signal 16: 139-144, 2004.

19. Qi SN, Yoshida A, Wang ZR and Ueda T: GP7 can induce apoptotic DNA fragmentation of human leukemia cells through caspase-3-dependent and -independent pathways. Int J Mol Med 13: 163-167, 2004.

20. Zhang JF, Liu JJ, Liu PQ, Lin DJ, Li XD and Chen GH: Oridonin inhibits cell growth by induction of apoptosis on human hepatocelluar carcinoma BEL-7402 cells. Hepatol Res 35: 104-110, 2006.

21. Thornberry NA and Lazebnik Y: Caspases: enemies within. Science 281: 1312-1316, 1998.

22. Subramaniam V, Vincent IR and Jothy S: Upregulation and dephosphorylation of cofilin: modulation by CD44 variant isoform in human colon cancer cells. Exp Mol Pathol 79: 187-193, 2005.

23. Martin SJ, Reutelingsperger CP, McGahon AJ, et al: Early redistribution of plasma membrane phosphatidylserine is a general feature of apoptosis regardless of the initiating stimulus: inhibition by overexpression of Bcl-2 and Abl. J Exp Med 182: 1545-1556, 1995

24. Donepudi M and Grutter MG: Structure and zymogen activation of caspases. Biophys Chem 101-102: 145-153, 2002.

25. Denault JB and Salvesen GS: Caspases: keys in the ignition of cell death. Chem Rev 102: 4489-4500, 2002.

26. Boatright KM and Salvesen GS: Caspase activation. Biochem Soc Symp: 233-242, 2003.

27. Philchenkov AA: Caspases as regulators of apoptosis and other cell functions. Biochemistry 68: 365-376, 2003.

28. Huether A, Hopfner M, Sutter AP, Schuppan D and Scherubl H: Erlotinib induces cell cycle arrest and apoptosis in hepatocellular cancer cells and enhances chemosensitivity towards cytostatics. J Hepatol 43: 661-669, 2005.

29. Nagata S: Apoptosis by death factor. Cell 88: 355-365, 1997.

30. Srinivasan A, Roth KA, Sayers RO, et al: In situ immunodetection of activated caspase-3 in apoptotic neurons in the developing nervous system. Cell Death Differ 5: 1004-1016, 1998.

31. Tanabe H, Eguchi Y, Shimizu S, Martinou JC and Tsujimoto Y: Death-signalling cascade in mouse cerebellar granule neurons. Eur J Neurosci 10: 1403-1411, 1998.

32. Bhathena SJ and Velasquez MT: Beneficial role of dietary phytoestrogens in obesity and diabetes. Am J Clin Nutr 76: 1191-1201, 2002.

33. Gross A, McDonnell JM and Korsmeyer SJ: BCL-2 family members and the mitochondria in apoptosis. Genes Dev 13: 1899-1911, 1999.

34. Oltvai ZN, Milliman CL and Korsmeyer SJ: Bcl-2 heterodimerizes in vivo with a conserved homolog, Bax, that accelerates programmed cell death. Cell 74: 609-619, 1993.

35. Choi YH, Kong KR, Kim YA, et al: Induction of Bax and activation of caspases during $\beta$-sitosterol-mediated apoptosis in human colon cancer cells. Int J Oncol 23: 1657-1662, 2003.

36. Levy P, Robin H, Bertrand F, Kornprobst M and Capeau J: Butyrate-treated colonic Caco-2 cells exhibit defective integrinmediated signaling together with increased apoptosis and differentiation. J Cell Physiol 197: 336-347, 2003.

37. White E: Life, death, and the pursuit of apoptosis. Genes Dev 10: $1-15,1996$. 